\title{
To Study Disruption by Cloud Computing in it Service Industry
}

\author{
SUBMITTED BY \\ MISS. SAMRUDDHI SHETTY \\ MIM - SEM V Roll No. 46 \\ UNDER THE GUIDANCE OF \\ PROF. SANDEEP KELKAR
IN PARTIAL FULFILLMENT OF MIM COURSE
University of Mumbai
(2016 - 2019)

Prin. L. N. Welingkar Institute of Management Development \& Research Matunga, Mumbai - 400019

\begin{abstract}
The research is conducted on the people serving IT Support and Development in various Sectors by filling an online questionnaire and interpreting the data collected by analysing demographically to find out opinion and thoughts about the disruption and ranking them and statistically by finding the associations between factors like reliability and the location of Data Center, Organization Culture and Disruption and between Security and Compliances and Regulatory. The research concluded that the Cloud Computing has brought Disruption in IT service Industry and population agrees to the statement but not strongly agree to it and Disruption will happen whether management supports the Innovation or Understands or not, it is the need of the hour. The main point of criticism for Cloud is concerns about security and privacy of Data which can be resolved with various compliances and Localization of Data Centers
\end{abstract}

Keywords: Disruption, Cloud Computing, IT Industry, Organization Culture, Cloud Security, Cloud Reliability 
Table of Content

\begin{tabular}{|c|c|}
\hline Definitions and Short forms & 124 \\
\hline List of Tables & 124 \\
\hline List of Charts & 125 \\
\hline List of Figures & 125 \\
\hline Chapters & \\
\hline 1. $\quad$ Introduction & 126 \\
\hline 1.1. Executive Summary & 126 \\
\hline 1.2. Objective & 126 \\
\hline 2. Literature Study and Conceptual Framework & 127 \\
\hline 2.1. What is Cloud Computing? & 127 \\
\hline 2.2. What is Disruption? & 128 \\
\hline 2.3. $\quad$ Literature Study & 129 \\
\hline 3. $\quad$ Research Design & 132 \\
\hline 3.1. Hypotheses & 132 \\
\hline 3.2. Source of Data and Sample Size & 133 \\
\hline 3.3. Tools used for collecting data & 133 \\
\hline 3.4. Limitation of Research & 134 \\
\hline 4. $\quad$ Primary Research & 135 \\
\hline 4.1. Tabulation of Data & 135 \\
\hline 4.2. Analysis & 136 \\
\hline 5. Findings and Observations & 146 \\
\hline 6. Conclusion & 147 \\
\hline Annexures & 147 \\
\hline Reference Table & 147 \\
\hline References & 148 \\
\hline
\end{tabular}




\section{Definitionsand Short forms}

\begin{tabular}{|l|l|}
\hline NIST & The National Institute of Standards and Technology US \\
\hline HIPPA & Health Insurance Portability and Accountability Act of 1996) United States \\
\hline MEITY & Ministry of Electronics and Information Technology India \\
\hline AWS & Amazon Web Service \\
\hline EC2 & Amazon Elastic Cloud Compute \\
\hline S3 & Amazon Simple Storage Service \\
\hline IaaS & Infrastructure as Service \\
\hline PaaS & Platform as Service \\
\hline SaaS & Software asService \\
\hline ARPANET & $\begin{array}{l}\text { ARPANET was the network that became the basis for the Internet. Based on a concept } \\
\text { first published in 1967, ARPANET was developed under the direction of the U.S. } \\
\text { Advanced Research Projects Agency (ARPA) }\end{array}$ \\
\hline
\end{tabular}

List of Tables

\begin{tabular}{|l|l|l|}
\hline Sr. No & \multicolumn{1}{|c|}{ Description } & Pg. No \\
\hline 1 & Literature Study & 129 \\
\hline 2 & Source Data and Sample Size & 133 \\
\hline 3 & Tabulation of Data for Demographic Analysis & 135 \\
\hline 4 & Tabulation of Data for Hypotheses Analysis & 136 \\
\hline 5 & Sector wise Demographic Analysis & 137 \\
\hline 6 & Gender wise Demographic Analysis & 137 \\
\hline 7 & Awareness wise Demographic Analysis & 138 \\
\hline 8 & Usage wise Demographic Analysis & 139 \\
\hline 9 & Cronbach Test Case Processing Summary & 139 \\
\hline 10 & Cronbach Test ReliabilityStatistics & 139 \\
\hline 11 & Factor Analysis Communalities & 140 \\
\hline 12 & Factor Anlysis1Total Variance Explained & 140 \\
\hline 13 & Hypothesis 1: Spearmen Correlation Case Processing Summary & 141 \\
\hline 14 & Hypothesis 1: Spearmen Correlation Security* Compliance Crosstabulation & 141 \\
\hline 15 & Hypothesis 1: Spearmen Correlation Symmetric Measures & 142 \\
\hline 16 & Hypothesis 2: Spearmen Correlation Case Processing Summary & 143 \\
\hline 17 & Hypothesis 2: Spearmen CorrelationReliabilty * DataCenterLocationCrosstabulation & 143 \\
\hline 18 & Hypothesis 2: Spearmen Correlation Symmetric Measures & 143 \\
\hline 19 & Hypothesis 3: Spearmen Correlation Case Processing Summary & 144 \\
\hline 20 & Hypothesis 3: Spearmen CorrelationDisruption* OrgCultureCrosstabulation & 144 \\
\hline 21 & Hypothesis 3: Spearmen Correlation Symmetric Measures & 145 \\
\hline
\end{tabular}




\section{List of Charts}

\begin{tabular}{|l|l|l|}
\hline Sr. No & \multicolumn{1}{|c|}{ Description } & Pg. No \\
\hline 1 & Bar Chart - Sector Wise Demographic Analysis & 136 \\
\hline 2 & Bar Chart - Gender Wise Demographic Analysis & 137 \\
\hline 3 & Bar Chart - Awareness Wise Demographic Analysis & 138 \\
\hline 4 & Bar Chart - Usage Wise Demographic Analysis & 138 \\
\hline 5 & Hypothesis 1 Scatter plot Diagram & 141 \\
\hline 6 & Hypothesis 2 Scatter plot Diagram & 142 \\
\hline 7 & Hypothesis 3 Scatter plot Diagram & 144 \\
\hline
\end{tabular}

\section{List of Figures}

\begin{tabular}{|l|l|l|}
\hline Sr. No & \multicolumn{1}{|c|}{ Description } & Pg. No \\
\hline 1 & As mentioned by the NIST, Cloud Computing have five key attributes & 127 \\
\hline 2 & Three different types of Services and Models of Cloud & 127 \\
\hline 3 & Qualities of Disruptive Company & 128 \\
\hline
\end{tabular}




\section{CHAPTER 1 INTRODUCTION}

\subsection{Executive Summary}

The Cloud Computing has brought new wave of innovation in Industry. In 2017 Cloud Computing was at the Slope of Enlightenment according to Gartner's Study report from the Trough of Disillusionment. Many IT Companies are adopting Cloud Computing and there is a change in the skill set requirement and practices followed because of Lots of Benefits and scaling the business needs cloud Bring in. So, this research concentrates on finding out whether Cloud Computing has brought Disruption in Market.

What are the Drivers and What are the main barriers Cloud Industry facing in achieving this. The association between the critical success factors and how they affect each other. The research also aims at finding the awareness and the knowledge IT population has about the technology and its effect on the day to day life of people when using personally and professionally. India is developing nation with many mid-scale and SMEs trying to build their businesses, to these industries Cloud Computing is providing infrastructure and IT support which will increase their flexibility and increase return on Investment.

The research concentrates on sample population views on Disruption brought by Cloud computing and it effect on their personal and professional life, the skill they had to acquire, different environments configured on Cloud Platform. Business applications developed and hosted on Cloud, their usage by IT people. The main focus is on the quantitative analysis on the factors affecting the Disruption and the inter relation among them whether they are strongly related or not related and their direction of relationship.

The research is conducted on the people serving IT Support and Development in various Sectors by filling an online questionnaire and interpreting the data collected by analysing demographically to find out opinion and thoughts about the disruption and ranking them and statistically by finding the associations between factors like reliability and the location of Data Center, Organization Culture and Disruption and between Security and Compliances and Regulatory.

The research concluded that the Cloud Computing has brought Disruption in IT service Industry and population agrees to the statement but not strongly agree to it and Disruption will happen whether management supports the Innovation or Understands or not, it is the need of the hour. The main point of criticism for Cloud is concerns about security and privacy of Data which can be resolved with various compliances and Localization of Data Centers.

\subsection{Objective}

1. To study the disruption and change in the IT service industry because of Cloud Computing and related technologies

2. To study the awareness about the Cloud Computing among the IT professionals and their thoughts about the disruption cloud computing has brought in business.

3. To study the usage of Cloud personally, professionally or both

4. To study the change and impact of Cloud Computing in various sectors in implementing IT solutions.

5. To study the factors which are critical and the drivers for the success and acceptance of Cloud Computing for various Business Solution

6. To study the factors which are barriers in implementing the cloud Computing and their association with each Other

7. To study the effect of data storage location on the reliability of Cloud Architecture

8. To study the effect of compliances on the IT Service Industry population's idea of Security over Cloud Architecture.

9. To study whether Organisation culture will affect the disruption brought by Cloud Computing. 


\section{CHAPTER 2 \\ LITERATURE STUDY AND CONCEPTUAL FRAMEWORK}

2.1 What is Cloud Computing?

Cloud computing is a kind of processing that depends sharing assets and resources so that there is better return on investment that is spent in acquiring assets.

It is more scalable and flexible, increasing and decreasing capacity on demands is the major benefit of cloud computing. User Applications, technology stacks and different way of controlling and monitoring are gotten to through the Web. The management and monitoring are communicated and consumed over the Internet and are paid for by the cloud customers on an as-required or pay-as-per-utilization needs and strategic plan. It does not depend on location. Pooling of resources and use of measured service are added attributes.

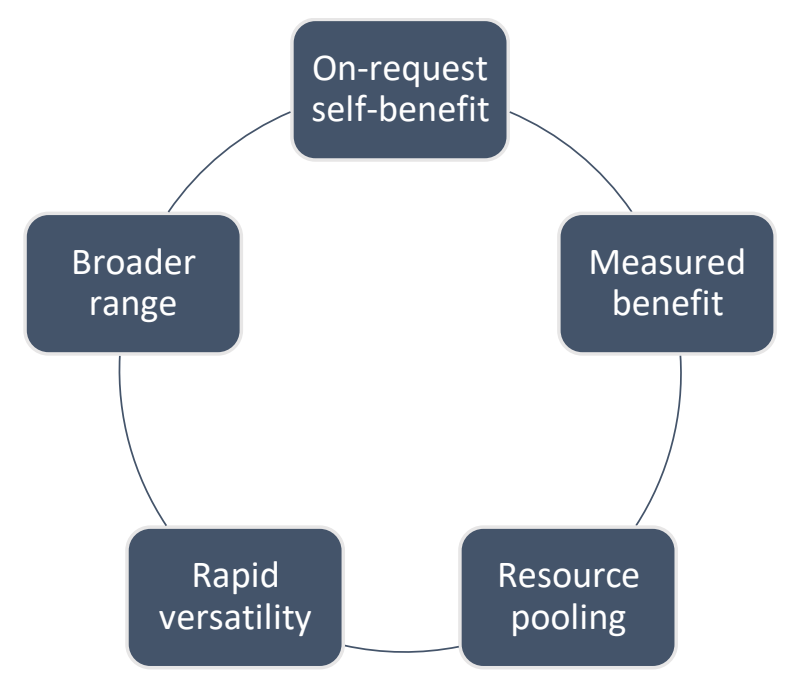

Fig 1. As mentioned by the NIST, CloudComputing has five key attributes

Cloud Models

\section{Iaas Infrastructure as Service}

- Customers use processing storage, networking and other computing resources from cloud service providers to run information systems. Example Amazon S3 and EC2 services

\section{PaaS Platform as Service}

-Customers use infrastructure and programming tools supported by the cloud service provider o develop their own application. For example, IBM offers Smart Business Application development.

\section{Saas Software as Service}

- Customers use software hosted by the vendor on the vendor's cloud infrastructure and delivered over a network.

Fig. 2. Three different types of Services and Models of Cloud 2.2. What is Disruption? 


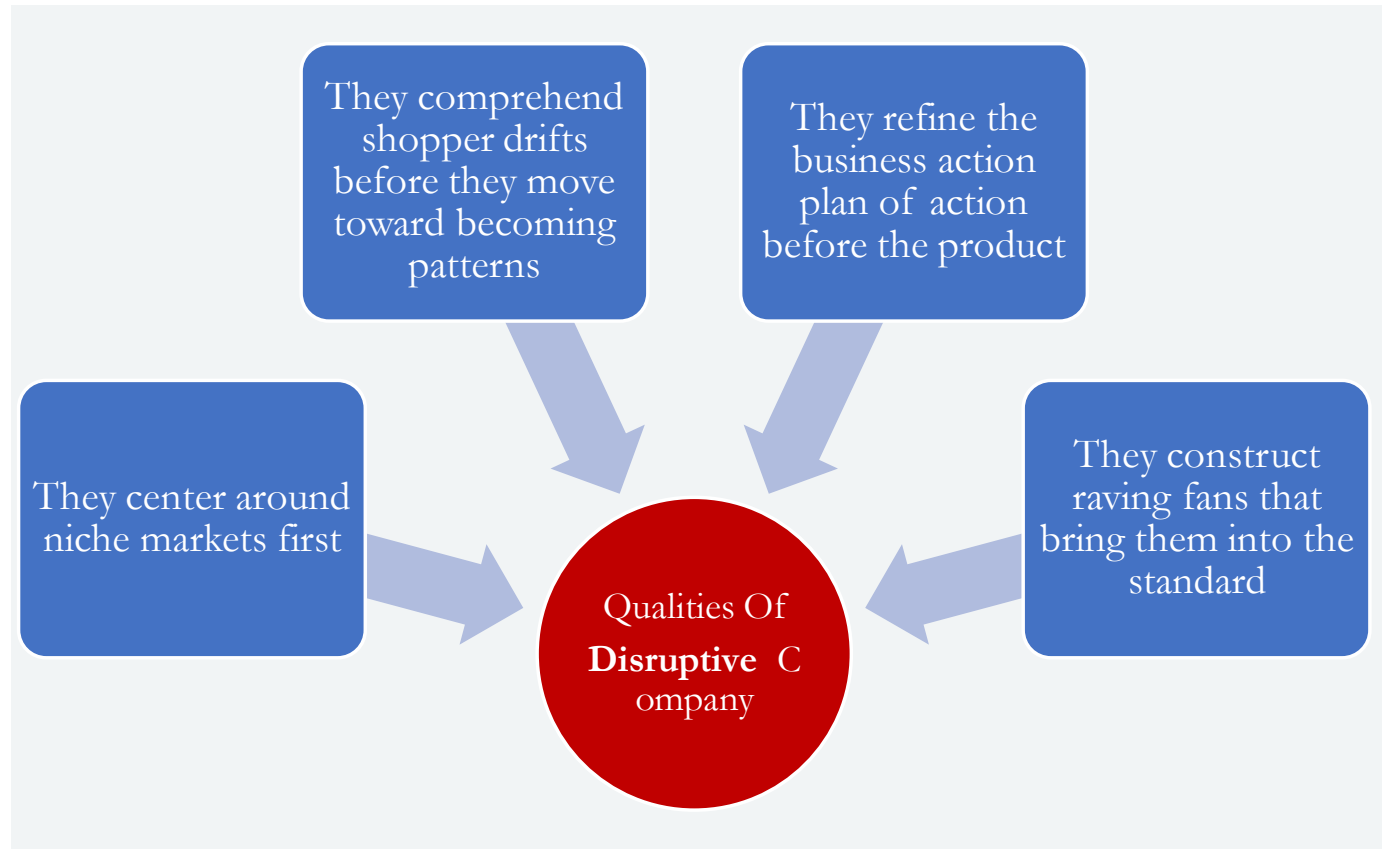

Fig 3. Qualities of Disruptive Company

"Disruptive innovation" " is a term instituted by Clayton Christensen, alluding to a procedure in which an underrated item or administration begins to wind up well sufficiently known to supplant, or uproot, an ordinary item or administration. In "genuine" problematic advancement, the item flourishes in the base of a market - and much of the time, builds up a terrible or low-class notoriety as a result of it. In any case, because of low costs, higher availability, or different focal points, the item in the long run turns out to be more engaging than its counterparts inside the business.

This is veered from "sustaining innovations," the new improvements and modifications made by tenant associations attempting to stay relevant with customers. These progressions can be noteworthy also, anyway a significant part of the time, things and organizations made in this manner end up being unreasonably refined, unnecessarily hard to reach, or too much exorbitant, making it unimaginable, making it difficult to have any authentic persisting power. In like way, customers look to more reasonable, now and again extreme decisions to address their issues.

The characterizing qualities of Disruption areare bring down gross edges, littler target markets, and items and administrations that are regularly less difficult than their contemporaries.

The issue with applying this term to any new business that difficulties an industry is that it undermines what genuine interruption is. It tends to draw in more thoughtfulness regarding new businesses that are as of now getting consideration, while the genuine disruptors are gradually climbing the step somewhere else, unnoticed by the business mammoths they're intended to supplant. 
Table 1

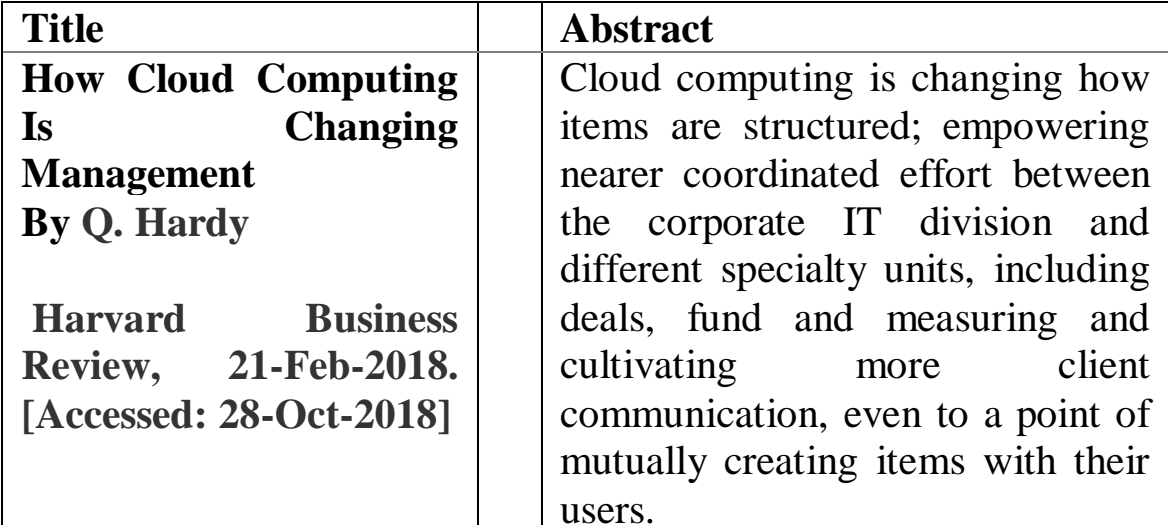

Augmentation

Techniques for Mobile

Cloud Computing: A

Taxonomy, Survey, and

Future Directions

By: Zhou, Bowen

Buyya, Rajkumar

ACM Computing

Surveys. Jan 2018

[Accessed: 28-Oct-

2018]
Regardless of the fast development of equipment limit and notoriety in cell phones, constrained assets in battery and preparing limit still come up short on the capacity to meet expanding portable clients' requests. Both ordinary strategies and rising methodologies are united to fill this hole between client request and cell phones' constrained capacities. Late research has concentrated on improving the execution of cell phones by means of enlargement strategies. Growth methods for portable distributed computing allude to the processing ideal models and answers for redistribute cell phone calculation and capacity to all the greater figuring assets with the end goal to upgrade a cell phone's registering ability and vitality proficiency (e.g., code offloading). Embracing enlargement methods in the heterogeneous and discontinuous versatile distributed computing condition makes new difficulties for calculation administration, vitality effectiveness,

\section{Takeaway}

It's basic to begin contemplating how administration will be changed by the most impactful data innovation within recent memory: distributed computing. What does it enable us to do any other way, and in what manner will that change the way we get things done later on? With cloud, data voyages quickly in the two bearings, crosswise over figuring frameworks that, with characteristics like virtualization, scaling up or down to deal with greater remaining tasks at hand, or mechanized security fixing across over a large number of machines, are undeniably adaptable.

To build the capacity of cell phones loads of enhancements and advancement have been embraced on the equipment front yet at the same time there is bunches of extension on programming and preparing end with the improvement in cloud-based administrations. One essential idea of HMC (Heterogeneous Mobile Cloud Computing) is clarified in detail and different programming dialects ideas like Java Reflection and .Net CLR and their capacities to utilize Service Oriented Architecture (SOA) have been investigated in this examination. From the client's viewpoint, client encounter on versatile applications and the elements of cell phones can be enhanced by presenting versatile distributed computing. For cloud specialist organizations, versatile mists empower an extensive client network to utilize their administrations. Moreover, suppliers can apply machine learning components on the administration information of cell phone clients to additionally, give more redid cloud administrations. Expanding portable design with Cloud Computing will 


\begin{tabular}{|c|c|c|}
\hline & $\begin{array}{l}\text { framework unwavering quality. In } \\
\text { this article, we plan to give a } \\
\text { complete scientific categorization } \\
\text { and overview of the current } \\
\text { strategies and systems for versatile } \\
\text { cloud enlargement in regard to } \\
\text { both calculation and capacity. }\end{array}$ & $\begin{array}{l}\text { improve the client encounter and can } \\
\text { increase the value of the cell phones. }\end{array}$ \\
\hline $\begin{array}{l}\text { Cloud Computing } \\
\text { Technology: Leveraging } \\
\text { the Power of The } \\
\text { Internet to Improve } \\
\text { Business Performance } \\
\text { By: Mohsen Attaran, } \\
\text { Ph.D. } \\
\text { Professor of Operations } \\
\text { Management } \\
\text { School of Business and } \\
\text { Public Administration } \\
\text { California } \\
\text { University } \\
\text { [Accessed: 28-Oct-2018] }\end{array}$ & $\begin{array}{l}\text { As of late, Cloud Computing } \\
\text { Technology (CCT) has risen as a } \\
\text { significant innovation that could } \\
\text { add to operational effectiveness of } \\
\text { an IT stage by giving foundation } \\
\text { and programming answers for the } \\
\text { entire IT requirements of an } \\
\text { undertaking by means of Internet. } \\
\text { The cloud has reformed IT } \\
\text { foundation. } \\
\text { It is anticipated that } 2017 \text { will } \\
\text { check the fast multiplication of } \\
\text { undertakings the cloud-based } \\
\text { progressing to the usage of } \\
\text { figuring innovation. The usang } \\
\text { this innovation makes } \\
\text { imaginative ing } \\
\text { cooperation less demanding among } \\
\text { organizations and has the } \\
\text { potential to make budgetary and } \\
\text { operational advantages. This } \\
\text { examination talks about } \\
\text { potential key advantages of this } \\
\text { innovation, features its advancing } \\
\text { advances } \\
\text { also, patterns and their future } \\
\text { effect, audits diverse stages } \\
\text { important to send } \\
\text { the innovation, features key } \\
\text { appropriation factors, and } \\
\text { overviews its potential application } \\
\text { in various ventures. }\end{array}$ & 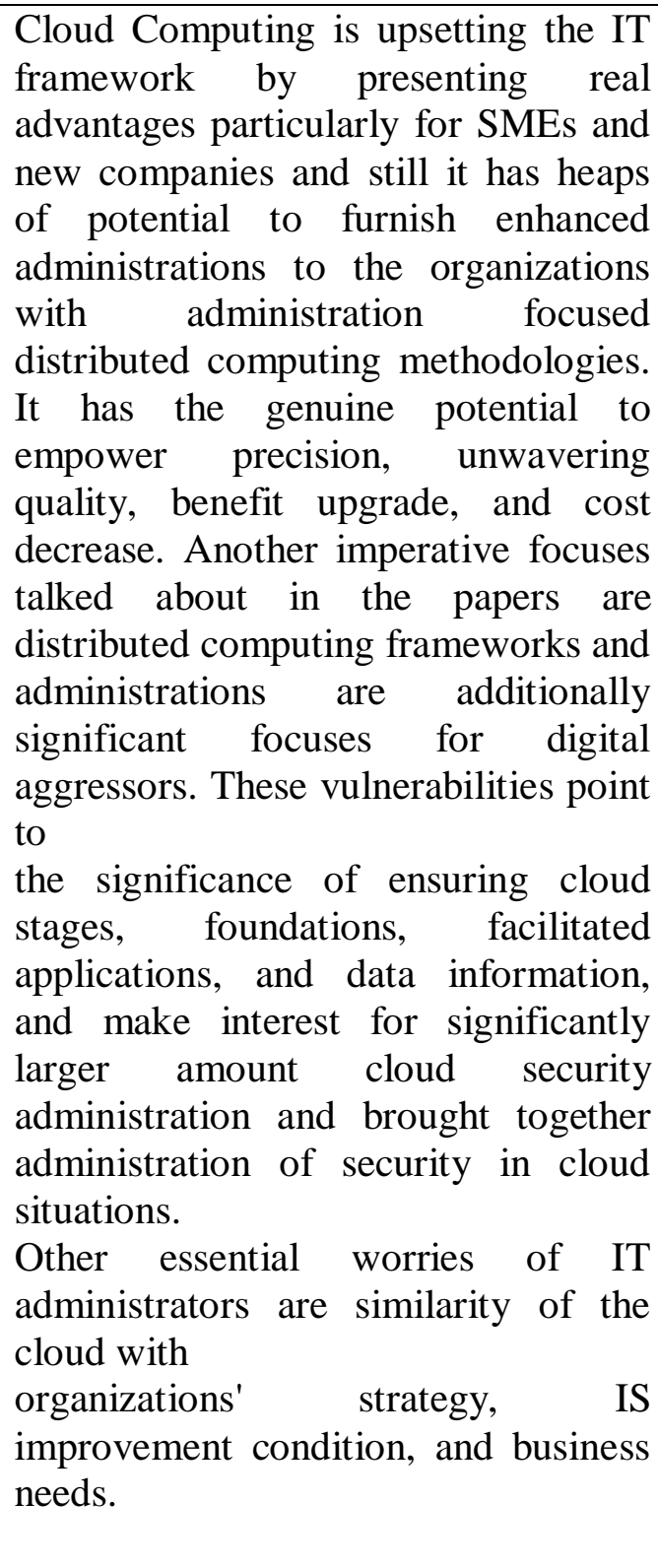 \\
\hline $\begin{array}{l}\text { The cloud impact on } \\
\text { outsourcing to India } \\
\text { By Rajiv Rao | July 14, } \\
2017 \\
\text { [Accessed: 28-Oct-2018] }\end{array}$ & $\begin{array}{l}\text { has changed the manner in which } \\
\text { organizations select which answers } \\
\text { for utilize, and the enormous } \\
\text { Indian IT firms are in effect } \\
\text { deserted. }\end{array}$ & $\begin{array}{l}\text { Indian IT business need to discover } \\
\text { ways and upgrade themselves that } \\
\text { detail how cloud can help support } \\
\text { deals, set up powerful estimating, } \\
\text { target clients all the more viably while } \\
\text { achieving new ones, and streamline } \\
\text { forms as a proactive measure to } \\
\text { manage change in pattern }\end{array}$ \\
\hline
\end{tabular}




\begin{tabular}{|c|c|c|}
\hline $\begin{array}{l}\text { What the future holds } \\
\text { for India in cloud } \\
\text { computing } \\
\text { By: Asoke K } \\
\text { LahaUpdated: July 27, } \\
2015 \text { [Accessed: 28-Oct- } \\
2018 \text { ] }\end{array}$ & $\begin{array}{l}\text { There is no doubt that India has } \\
\text { gigantic abilities to wind up a } \\
\text { worldwide center point for cloud } \\
\text { computing. The fate of cloud } \\
\text { computing and also profession } \\
\text { openings in the field sparkles } \\
\text { splendid for India. }\end{array}$ & $\begin{array}{l}\text { Cloud Computing cuts down the } \\
\text { expense and labour prerequisites since } \\
\text { the exorbitant programming bundles } \\
\text { and equipment frameworks expected } \\
\text { to introduce them are never again } \\
\text { required which encourages us to climb } \\
\text { in advanced Value chain. It has an } \\
\text { immediate and high advantages for } \\
\text { little to medium estimated } \\
\text { organizations (SMBs) }\end{array}$ \\
\hline $\begin{array}{l}\text { Cloud Success story in } \\
\text { India } \\
\text { By: Asvija B } \\
\text { Center for Development } \\
\text { of Advanced Computing } \\
\text { (C-DAC), } \\
\text { Bangalore. } \\
\text { INDIA } \\
27 \text { June 2014 ASREN } \\
\text { Workshop on Clouds } \\
\text { for Research and } \\
\text { Education, rtaly. } \\
\text { [Accessed: 28-Oct-2018] }\end{array}$ & $\begin{array}{l}\text { With the end goal to use and } \\
\text { saddle the advantages of Cloud } \\
\text { Computing, Government of India } \\
\text { has left upon an aspiring activity - } \\
\text { "GI Cloud" which has been named } \\
\text { as 'MeghRaj'. The focal point of } \\
\text { this activity is to quicken } \\
\text { conveyance of e-benefits in the } \\
\text { nation while enhancing ICT } \\
\text { spending of the Government. }\end{array}$ & $\begin{array}{l}\text { Cloud Awareness and eagerness for } \\
\text { selection is expanding and } \\
\text { Government has perceived its } \\
\text { significance and colossal business } \\
\text { potential by attempting strategies and } \\
\text { taking endeavours. Organizations are } \\
\text { likewise eager to grow their base by } \\
\text { giving better administrations, yet } \\
\text { challenges remain: } \\
\text { Foundation front } \\
\text { Mentality of clients } \\
\text { Developing benchmarks. }\end{array}$ \\
\hline
\end{tabular}




\section{CHAPTER 3 RESEARCH DESIGN}

To better define the scope and limitations of this project, software engineers, consultants, team leads, students from various IT organisations and Educational Institutes will be studied. Primary research will be done by collecting data through an information gathering, survey and observation methods.

\subsection{Research Problem and Hypotheses Statements}

3.1.1. Hypothesis 1

"To study the association of Compliance and Regulatory Standards with Security of Cloud Computing in bringing Disruption in IT Service Industry"

The majorbarrier and matter of criticism for cloud computing is preserving confidentiality and integrity of data in aiding data security and the compliances associated which are not much developed. The major difference between security of Cloud and compliances and regulatory standards is that security is intrinsically risk-based whereas Compliance and Standards are determined by legislative, non-profit or industry groups and serves as a general design for the security of convinced classes of data.

Null Hypothesis $\left(\mathbf{H}_{\mathbf{0}}\right)$ : There is no significant association between Security and the Compliance and Regulatory Standardsof Cloud Computing for bringing Disruption in IT Service Industry

Alternative Hypothesis $\left(\mathbf{H}_{\mathbf{a}}\right)$ : There is significant association between Security and the Compliance and Regulatory Standardsof Cloud Computing for bringing Disruption in IT Service Industry

\subsubsection{Hypothesis 2}

"To study the association of Reliabilitywith the Location of Data Centers of Cloud Computing in bringing Disruption in IT Service Industry"

The purpose of capacity is an essential one in the GDPR talk from cloud suppliers, to showcasing frameworks, instruments and CRMs, to the specific server farm that guarantees to safely store the individual information of big business clients. "Govt IT data on cloud system must be stored within India:" necessitated Meity . Considering GDPR concerns and Indian Government's demand to set up Data Centers within the country's boundary and stress on localization of data, "Does the location of Data Center gives the reliability assurance to customers and makes Cloud Computing more acceptable and trust worthy" is point to be considered.

Null Hypothesis $\left(\mathbf{H}_{\mathbf{0}}\right)$ : There is no significant association between Reliability and the Location of Data Center of Cloud Computing for bringing Disruption in IT Service Industry

Alternative Hypothesis $\left(\mathbf{H}_{\mathbf{a}}\right)$ : There is significant association between Organization Culture and the Disruptionbrought by Cloud Computing in IT Service Industry

\subsubsection{Hypothesis 3}

"To study the association of Organization Culturewith Disruption brought by Cloud Computing in IT Service Industry"

Since 2007, cloud computing has developed as a registering worldview that is probably going to change many the conventional methods for conveying processing administrations to individuals and associations. Numerous associations, little and extensive, have grasped it considering the focal points it guarantees as far as adaptable cost structure, versatility and effectiveness. However, does organization culture affects the disruption or there will be disruption in the industry irrespective of the organization culture, they must accept the cloud computing and move ahead to reap the benefits of implementing the Cloud Technology. 
Null Hypothesis $\left(\mathbf{H}_{0}\right)$ : There is no significant association between Organization Culture and the Disruptionbrought by Cloud Computing in IT Service Industry

Alternative Hypothesis $\left(\mathbf{H}_{\mathbf{a}}\right)$ : There is significant association between Organization Culture and the Disruptionbrought by Cloud Computing in IT Service Industry

\subsection{Source of Data and Sample Size}

The sample participants consist of population working in IT service Industry. Mostly salaried Individuals with Age Group of 25-30 years (Millennials) and are early adaptors of Innovation and Disruption.

Table 2

\begin{tabular}{|c|c|c|c|}
\hline Occupation & Age Group in years & & \\
\hline & $\mathbf{1 8 - 2 5}$ & $\mathbf{2 6 - 3 5}$ & Grand Total \\
\hline Business & & 4 & 4 \\
\hline IT & 1 & & 1 \\
\hline Salaried & 4 & 59 & 63 \\
\hline Salaried, Student & & 1 & 1 \\
\hline Self- Employed & & 2 & 2 \\
\hline Self- Employed, Business, Salaried & 2 & 1 & 1 \\
\hline Student & $\mathbf{7}$ & 2 & 4 \\
\hline Grand Total & $\mathbf{6 9}$ & $\mathbf{7 6}$ \\
\hline
\end{tabular}

Participants will be the Managers, Team Lead, Consultants from IT Service Industry and Students pursuing education on Information Technology. Their understanding about the factors contributing to success of Cloud Computing as well as the factors which are barriers for Cloud Computing

\subsection{Tools used for Collecting Data}

The survey instrument will consist of questions that address role and impact of Cloud Computing technology:

- A structured questionnaire will be used to interview IT Professionals and Students regarding Disruption and Innovation brought by Cloud Computing in the Industry and their awareness and thoughts regarding its future.

- Cloud Computing Models opted and plans to opt in future through online survey.

- Questions with 5-point scale base on factors responsible for Disruption.

- Participants would be encouraged to provide their level of experience with technology and implementation in various Development Practices and Environment.

- Participants would deliver their level of mindfulness in Cloud innovation.

Both qualitative and quantitative data will be used and then be statistically analysed for the research. Qualitative analysis will be used to study the awareness among the people working in IT Service Industry and their idea about disruption and acceptance in using Cloud Computing in various environment. Quantitative analysis will be used to study the association between various critical factors acting as barrier or driving force for Cloud Computing. 
3.4 Limitation of Research

- The scope of the research is limited to India, where sample size is very small and only few organization's population has responded to survey. The survey and effect can be conducted for more specific sectors and related factors associated can be measured more precisely.

- Further the scope is limited to few organizations, there can be bifurcation between organizations on CMMI Level or SMEs, thus it can be expanded for all further research.

- The technologies are being upgraded very often like Block Chains, Artificial Intelligence, Big Data and various Automation Tools including DevOps practices. Integration of Cloud Computing with these technologies and its effect on Disruption in the Industry can be studied more deeply.

- IT Service People are more informed and technology friendly thus the future scope of a conducive development and innovation in Cloud Computing is very high. The present study thus is limited to current scenarios.

- There are more specific GDPR policies which are implemented or in process in country like India so more compliance related and its effect on reliability, security and robustness and its effect on Disruption By Cloud Computing can be studied more specifically and keeping defined points in focus. 


\section{CHAPTER 4 PRIMARY RESEARCH}

4.1 Tabulation of Data

4.1.1. Tabulation of Data for Demographic Analysis

Note: The actual sample size is 76 but for Tabulation Purpose top 10 records have been displayed.

Table 3

\begin{tabular}{|c|c|c|c|c|c|}
\hline $\begin{array}{l}\text { Sr. } \\
\text { No }\end{array}$ & Gender & Sector & $\begin{array}{l}\text { Are you aware } \\
\text { of Cloud } \\
\text { Computing? }\end{array}$ & $\begin{array}{l}\text { Have you } \\
\text { ever used } \\
\text { Cloud } \\
\text { Computin } \\
\text { g? }\end{array}$ & $\begin{array}{c}\text { Has Cloud } \\
\text { Computing } \\
\text { created } \\
\text { Disruption in IT } \\
\text { Service } \\
\text { Industry?(Rating) }\end{array}$ \\
\hline 1 & Male & $\begin{array}{c}\text { ICT (Information } \\
\text { Communication and } \\
\text { Technology) }\end{array}$ & $\begin{array}{l}\text { I know what is } \\
\text { cloud computing }\end{array}$ & Both & 4 \\
\hline 2 & Female & Others & $\begin{array}{l}\text { I have some } \\
\text { knowledge about } \\
\text { cloud computing }\end{array}$ & Personally & 5 \\
\hline 3 & Male & Others & $\begin{array}{l}\text { I have some } \\
\text { knowledge about } \\
\text { cloud computing }\end{array}$ & None & 3 \\
\hline 4 & Male & Real Estate & $\begin{array}{l}\text { I have some } \\
\text { knowledge about } \\
\text { cloud computing }\end{array}$ & None & 5 \\
\hline 5 & Male & $\begin{array}{c}\text { ICT (Information } \\
\text { Communication And } \\
\text { Technology) }\end{array}$ & $\begin{array}{l}\text { I have some } \\
\text { knowledge about } \\
\text { cloud computing }\end{array}$ & None & 5 \\
\hline 6 & Female & Others & $\begin{array}{l}\text { I have some } \\
\text { knowledge about } \\
\text { cloud computing }\end{array}$ & Personally & 4 \\
\hline 7 & Female & $\begin{array}{c}\text { ICT (Information } \\
\text { Communication And } \\
\text { Technology) }\end{array}$ & $\begin{array}{l}\text { I have some } \\
\text { knowledge about } \\
\text { cloud computing }\end{array}$ & $\begin{array}{l}\text { Profession } \\
\text { ally }\end{array}$ & 5 \\
\hline 8 & Male & Banking and Financial services & $\begin{array}{l}\text { I have some } \\
\text { knowledge about } \\
\text { cloud computing }\end{array}$ & None & 4 \\
\hline 9 & Female & Others & $\begin{array}{l}\text { I know what is } \\
\text { cloud computing }\end{array}$ & Both & 5 \\
\hline 10 & Female & Others & $\begin{array}{l}\text { I know what is } \\
\text { cloud computing }\end{array}$ & Both & 3 \\
\hline
\end{tabular}

4.1.2. Tabulation of Data for Hypotheses Analysis

Data is Rating Based on the various Factors which are critical for the disruption of Cloud Computing. Hypotheses are based on the association between these factors and whether they are strongly or weakly related to each other and their direction whether positive or negative.

Org Culture is the ordinal and combined variable which is calculated by the average of Management Willingness and Organization Politics. 
Disruption, Reliability, Data Center Location, Security and Compliance are the factors which are rated by the survey population.

Note: The actual sample size is 76 but for Tabulation Purpose top 10 records have been displayed.

$\underline{\text { Table } 4}$

\begin{tabular}{|c|c|c|c|c|c|c|c|c|}
\hline Sr. No & Disruption & $\begin{array}{l}\text { Management } \\
\text { Willing to } \\
\text { Innovate(A) }\end{array}$ & $\begin{array}{l}\text { Org } \\
\text { Politics(B) }\end{array}$ & Org Culture (Avg of A and B) & Reliability & Data Canter Location & Security & Compliance \\
\hline 1 & 4 & 2 & 5 & 3.5 & 2 & 4 & 5 & 4 \\
\hline 2 & 5 & 4 & 3 & 3.5 & 2 & 4 & 5 & 4 \\
\hline 3 & 3 & 5 & 2 & 3.5 & 3 & 3 & 3 & 4 \\
\hline 4 & 5 & 1 & 1 & 1 & 5 & 5 & 1 & 5 \\
\hline 5 & 5 & 3 & 2 & 2.5 & 2 & 2 & 3 & 3 \\
\hline 6 & 4 & 1 & 2 & 1.5 & 5 & 4 & 3 & 1 \\
\hline 7 & 5 & 3 & 1 & 2 & 4 & 4 & 4 & 4 \\
\hline 8 & 4 & 5 & 5 & 5 & 1 & 1 & 2 & 3 \\
\hline 9 & 5 & 2 & 2 & 2 & 3 & 2 & 5 & 5 \\
\hline 10 & 3 & 2 & 3 & 2.5 & 2 & 2 & 2 & 3 \\
\hline
\end{tabular}

\subsection{Analysis}

4.2.1. Demographic Analysis

4.2.1.1. Sectorwise

Chart 1

\section{HAS CLOUD COMPUTING CREATED DISRUPTION IN IT SERVICE INDUSTRY? (SECTOR WISE RATING)}

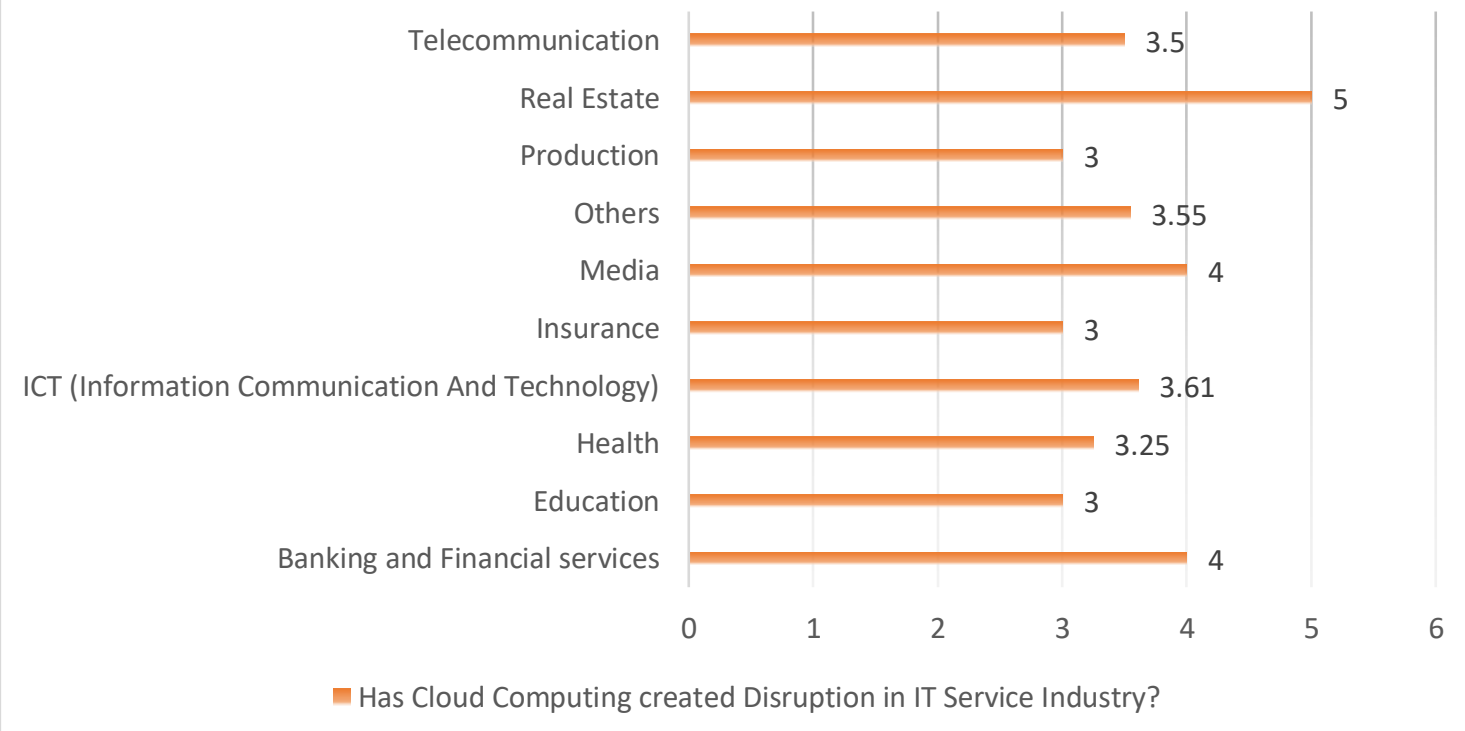


Table 5

\begin{tabular}{|c|c|c|}
\hline Sectors & Average Rating & No. of Respondents \\
\hline Banking and Financial services & 4 & 7 \\
\hline Education & 3 & 1 \\
\hline Health & 3.25 & 4 \\
\hline ICT (Information Communication and Technology) & 3.61 & 36 \\
\hline Insurance & 3 & 1 \\
\hline Media & 4 & 1 \\
\hline Others & 3.55 & 22 \\
\hline Production & 3 & 1 \\
\hline Real Estate & 5 & 1 \\
\hline Telecommunication & 3.5 & 2 \\
\hline Grand Total & $\mathbf{3 . 6 1}$ & $\mathbf{7 6}$ \\
\hline
\end{tabular}

Sector wise, demo graphic shows Cloud Computing has brought disruption since 3.6 Rating on Average shows population somewhat agrees on the statement.

\subsubsection{Gender wise}

\section{Chart 2}

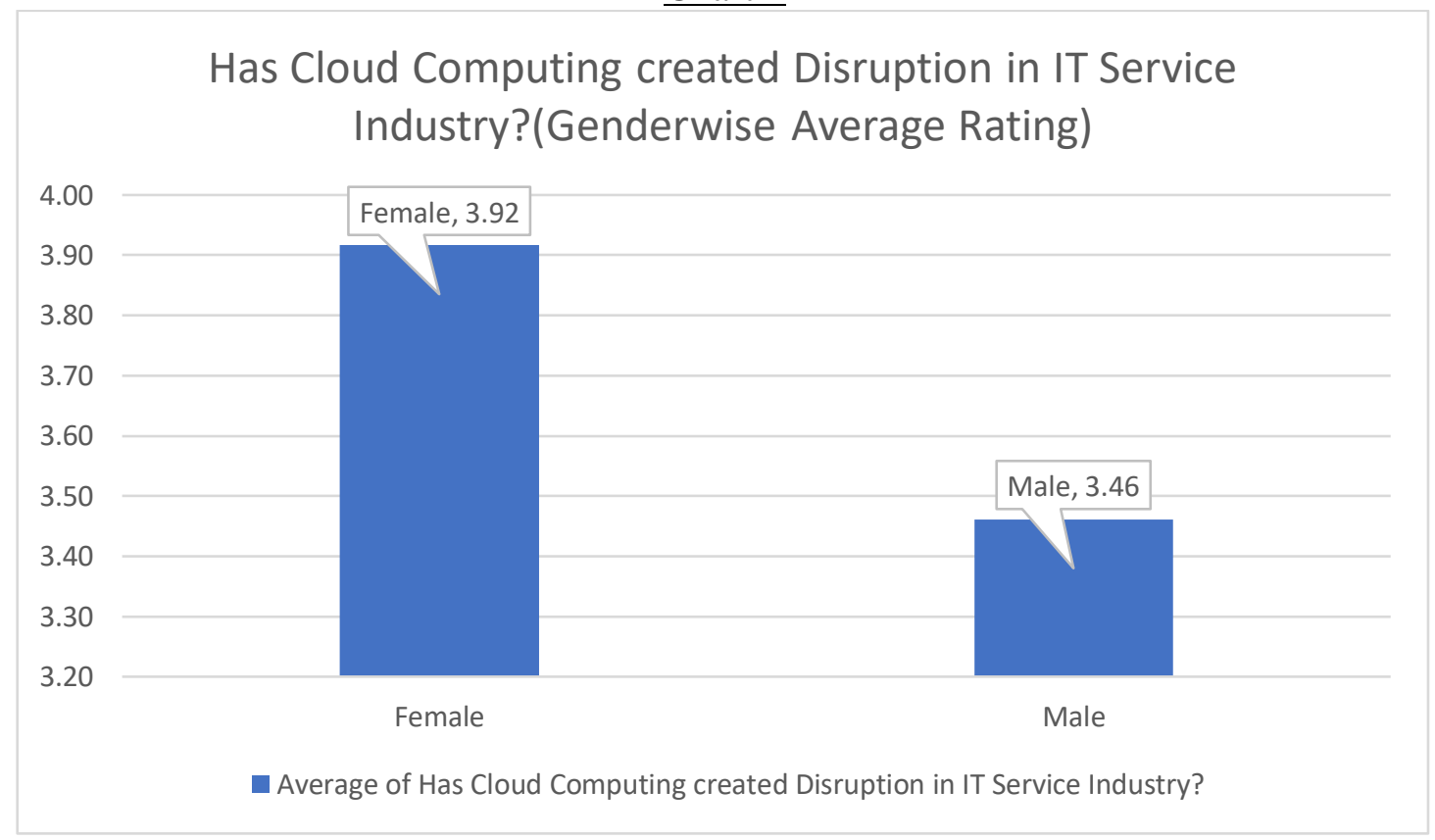

Table 6

\begin{tabular}{|c|c|c|}
\hline Gender & Average Rating & No. of Respondents \\
\hline Female & 3.92 & 24 \\
\hline Male & 3.46 & 52 \\
\hline Total & $\mathbf{3 . 6 1}$ & $\mathbf{7 6}$ \\
\hline
\end{tabular}

Gender wise Female Population Agree more on the statements as compared to malepopulation. 
4.2.1.3. Awareness and Knowledge wise

\section{$\underline{\text { Chart } 3}$}

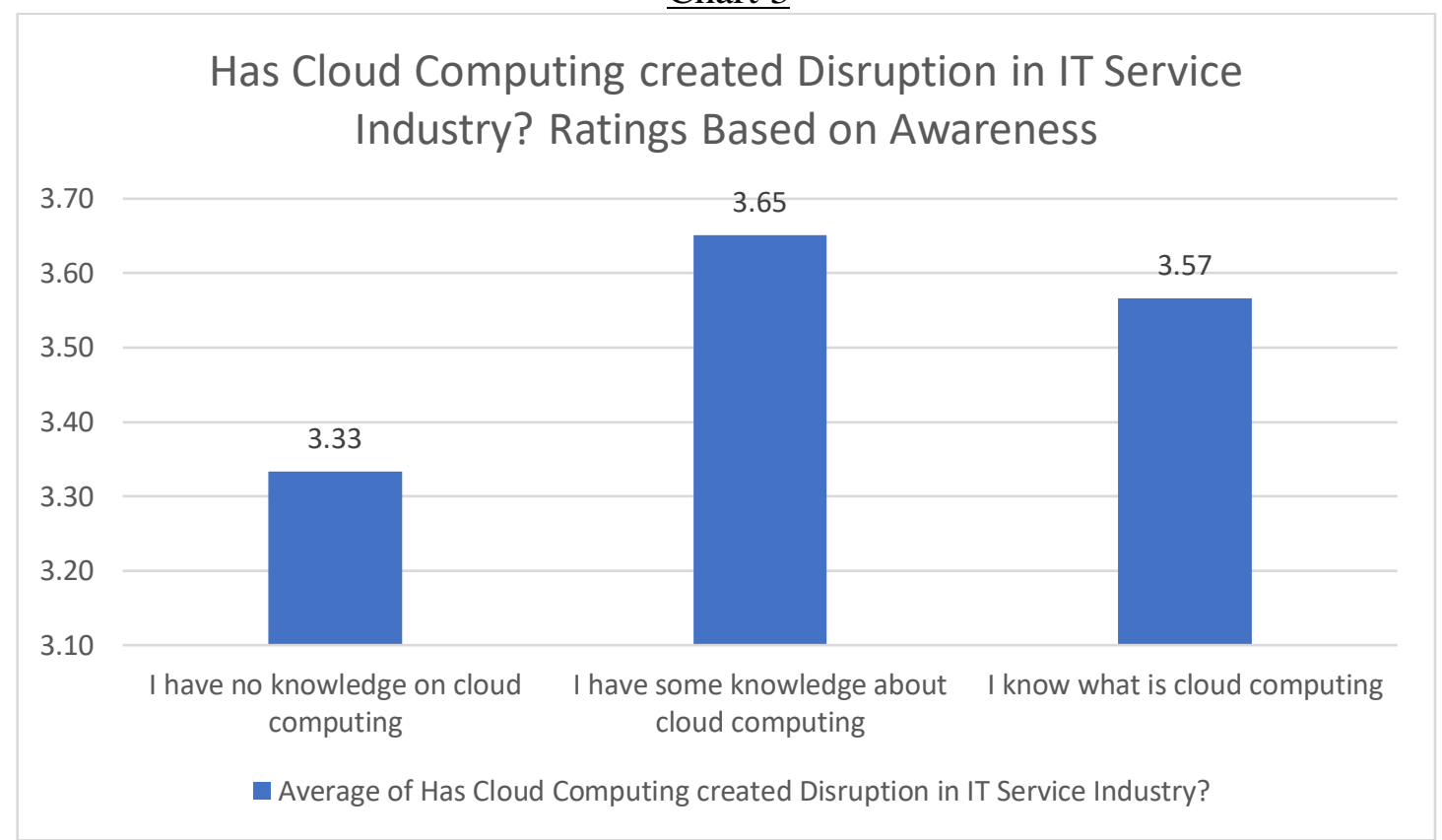

Table 7

\begin{tabular}{|c|c|c|}
\hline Awareness & Average Rating & No. of Respondents \\
\hline I have no knowledge on cloud computing & 3.33 & 3 \\
\hline I have some knowledge about cloud computing & 3.65 & 43 \\
\hline I know what is cloud computing & 3.57 & 30 \\
\hline Grand Total & $\mathbf{3 . 6 1}$ & $\mathbf{7 6}$ \\
\hline
\end{tabular}

Awareness and knowledge wise, although people don't have technical knowledge and actual working of Cloud Computing, still,they are of the opinion that Cloud Computing is bringing Disruption in Industry.

\subsubsection{Usage wise}

Chart 4

\section{Has Cloud Computing created Disruption in IT Service Industry? Ratings Based on Usage}

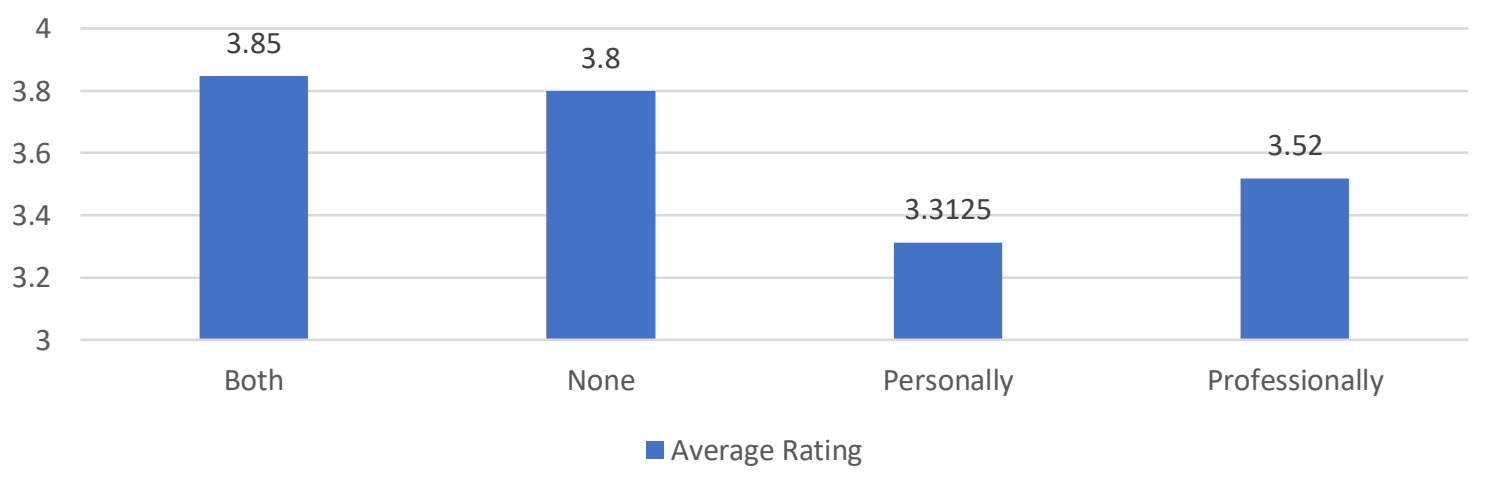


Table 8

\begin{tabular}{|c|c|c|}
\hline Usage & Average Rating & No. of Respondents \\
\hline Both & 3.85 & 13 \\
\hline None & 3.8 & 20 \\
\hline Personally & 3.32 & 16 \\
\hline Professionally & 3.52 & 27 \\
\hline Grand Total & $\mathbf{3 . 6 1}$ & $\mathbf{7 6}$ \\
\hline
\end{tabular}

Based on usage of cloud platforms, personally professionally or both, population agrees that Cloud computing has brought change in their experience and it is pleasant and innovative and will go long way making impact in their day to day life.

\subsubsection{Hypotheses Analysis}

\subsubsection{Cronbach's alpha -Reliability and Consistency Test}

Cronbach's alpha is a measure of internal consistency, that is, how closely related a set of items are as a group. It is considered to be a measure of scale reliability. It is a coefficient of reliability (or consistency).

\section{Table 9- Case Processing Summary}

\begin{tabular}{|l|l|l|l|}
\hline \multicolumn{2}{|l|}{} & N & $\%$ \\
\hline Cases & Valid & 76 & 90.5 \\
\cline { 2 - 4 } & Excluded $^{\mathrm{a}}$ & 8 & 9.5 \\
\cline { 2 - 4 } & Total & 84 & 100.0 \\
\hline
\end{tabular}

\begin{tabular}{|c|c|c|}
\hline \multicolumn{2}{|c|}{ Table 10- Reliability Statistics } \\
\hline Cronbach's Alpha & $\begin{array}{c}\text { Cronbach's Alpha Based on } \\
\text { Standardized Items }\end{array}$ & N of Items \\
\hline .826 & .816 & 6 \\
\hline
\end{tabular}

The alpha coefficient for the four items is .826 , suggesting that the items have relatively high internal consistency. (Note that a reliability coefficient of .70 or higher is considered "acceptable" in most social science research situations.)

In addition to computing the alpha coefficient of reliability, we might also want to investigate the dimensionality of the scale. We can use the factor Analysis to do this: 


\subsubsection{Factor Analysis}

\begin{tabular}{|c|c|c|}
\hline \multicolumn{2}{|c|}{ Table 11- Communalities } \\
\hline & Initial & Extraction \\
\hline Disruption & 1.000 & .803 \\
\hline OrgCulture & 1.000 & .615 \\
\hline Reliabilty & 1.000 & .679 \\
\hline DataCenterLocation & 1.000 & .780 \\
\hline Security & 1.000 & .688 \\
\hline Compliance & 1.000 & .749 \\
\hline \multicolumn{2}{|c|}{ Extraction Method: Principal Component Analysis. } \\
\hline
\end{tabular}

\begin{tabular}{|c|c|c|c|c|c|c|}
\hline \multicolumn{7}{|c|}{ Table 12- Total Variance Explained } \\
\hline \multirow{2}{*}{ Component } & \multicolumn{7}{|c|}{$\begin{array}{c}\text { Initial Eigenvalues } \\
\text { Total }\end{array}$} & $\begin{array}{c}\% \text { of } \\
\text { Variance }\end{array}$ & $\begin{array}{c}\text { Cumulative } \% \\
\text { Totraction Sums of Squared Loadings }\end{array}$ & Total & \% of Variance & Cumulative \% \\
\hline & 3.301 & 55.021 & 55.021 & 3.301 & 55.021 & 55.021 \\
\hline 1 & 1.012 & 16.875 & 71.895 & 1.012 & 16.875 & 71.895 \\
\hline 2 & .672 & 11.207 & 83.102 & & & \\
\hline 3 & .481 & 8.013 & 91.115 & & & \\
\hline 5 & .306 & 5.107 & 96.223 & & & \\
\hline 6 & .227 & 3.777 & 100.000 & & \\
\hline \multicolumn{7}{|c|}{ Extraction Method: Principal Component Analysis. } \\
\hline
\end{tabular}

Looking at the table labelled Total Variance Explained, we see that the eigen value for the first factor is quite a bit larger than the eigen value for the next factor (3.30 versus 1.01). Additionally, the first factor accounts for $55.021 \%$ of the total variance. This suggests that the scale items are unidimensional.

\subsubsection{Hypothesis 1 Testing}

Null Hypothesis $\left(\mathbf{H}_{\mathbf{0}}\right)$ : There is no significant association between Security and the Compliance and Regulatory Standardsof Cloud Computing for bringing Disruption in IT Service Industry

Alternative Hypothesis $\left(\mathbf{H}_{\mathbf{a}}\right)$ : There is significant association between Security and the Compliance and Regulatory Standardsof Cloud Computing for bringing Disruption in IT Service Industry 4.2.2.3.1. Scatter plot Diagram 


\section{$\underline{\text { Chart } 5}$}

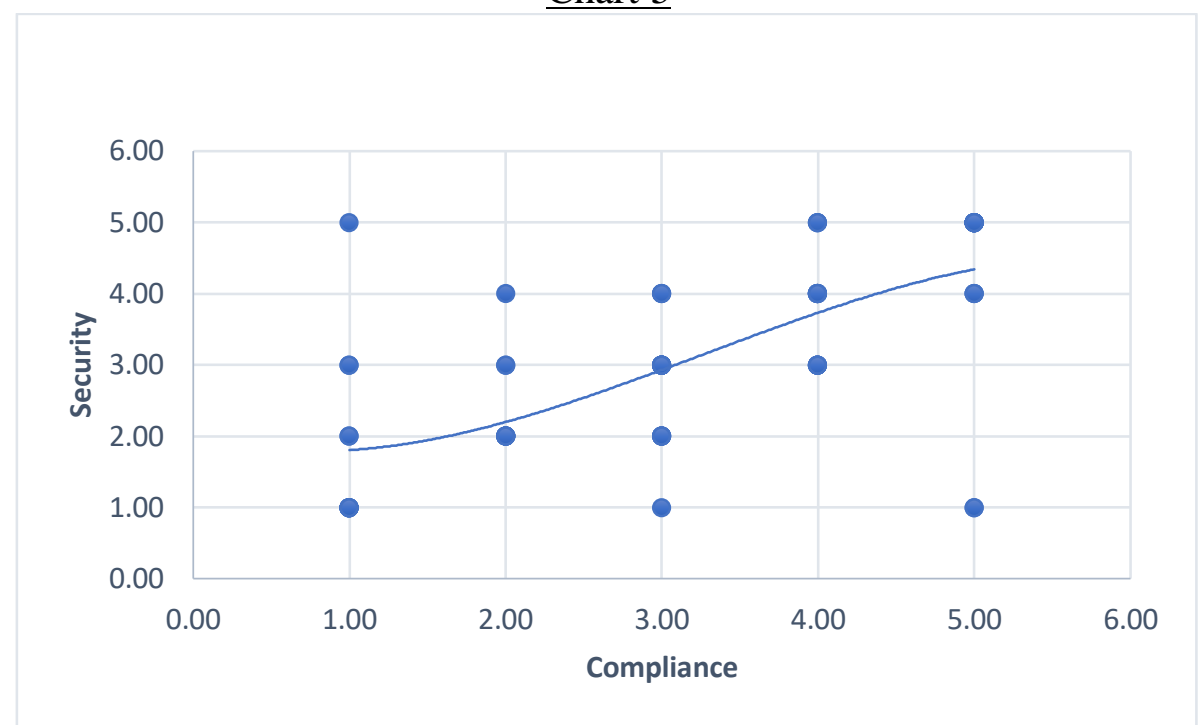

The relationship appears monotonic (assessed via scatterplot).there is a monotonic component to the association, as the value of compliance increases, so does the value of the security.

Since both are ranked variable, we can run Spearman's correlation to measure the strength and direction of this monotonic relationship.

4.2.2.3.2 Spearman Correlation

\begin{tabular}{|c|c|c|c|c|c|c|}
\hline \multicolumn{7}{|c|}{ Table 13- Case Processing Summary } \\
\hline & \multicolumn{6}{|c|}{ Cases } \\
\hline & \multicolumn{2}{|c|}{ Valid } & \multicolumn{2}{|c|}{ Missing } & \multicolumn{2}{|c|}{ Total } \\
\hline & $\mathrm{N}$ & Percent & $\mathrm{N}$ & Percent & $\mathrm{N}$ & Percent \\
\hline Security * Compliance & 76 & $90.5 \%$ & 8 & $9.5 \%$ & 84 & $100.0 \%$ \\
\hline
\end{tabular}

\begin{tabular}{|c|c|c|c|c|c|c|c|}
\hline \multicolumn{8}{|c|}{ Table 14- Security * Compliance Crosstabulation } \\
\hline \multicolumn{8}{|c|}{ Count } \\
\hline & & \multicolumn{5}{|c|}{ Compliance } & \multirow[b]{2}{*}{ Total } \\
\hline & & 1.00 & 2.00 & 3.00 & 4.00 & 5.00 & \\
\hline \multirow[t]{5}{*}{ Security } & 1.00 & 8 & 0 & 1 & 0 & 2 & 11 \\
\hline & 2.00 & 2 & 8 & 5 & 0 & 0 & 15 \\
\hline & 3.00 & 2 & 2 & 9 & 6 & 0 & 19 \\
\hline & 4.00 & 0 & 1 & 3 & 9 & 3 & 16 \\
\hline & 5.00 & 1 & 0 & 0 & 3 & 11 & 15 \\
\hline \multicolumn{2}{|c|}{ Total } & 13 & 11 & 18 & 18 & 16 & 76 \\
\hline
\end{tabular}


ISSN No:-2456-2165

Table 15- Symmetric Measures

\begin{tabular}{|c|c|c|c|c|}
\hline & Value & $\begin{array}{l}\text { Asymptotic } \\
\text { Standard Error }\end{array}$ & Approximate $\mathrm{T}^{\mathrm{b}}$ & $\begin{array}{l}\text { Approximate } \\
\text { Significance }\end{array}$ \\
\hline Interval by Interval Pearson's R & .683 & .096 & 8.046 & $.000^{\mathrm{c}}$ \\
\hline Ordinal by Ordinal Spearman Correlation & .692 & .093 & 8.249 & $.000^{\mathrm{c}}$ \\
\hline $\mathrm{N}$ of Valid Cases & 76 & & & \\
\hline
\end{tabular}

Here the significance Value is 0.00 so, we will reject the null hypothesis $\left(\mathrm{H}_{0}\right)$ and accept the alternative hypothesis $\left(\mathrm{H}_{\mathrm{a}}\right)$. So, these two variables have strong association since Spearman Correlation value is 0.692 and in positive direction that means Security will increase if compliance will increase.

This proves,

There is significant association between Security and the Compliance and Regulatory Standards of Cloud Computing for bringing Disruption in IT Service Industry.

\subsubsection{Hypothesis 2 Testing}

Null Hypothesis $\left(\mathbf{H}_{\mathbf{0}}\right)$ : There is no significant association between Reliability and the Location of Data Center of Cloud Computing for bringing Disruption in IT Service Industry

Alternative Hypothesis $\left(\mathbf{H}_{\mathbf{a}}\right)$ : There is significant association between Organization Culture and the Disruptionbrought by Cloud Computing in IT Service Industry

4.2.2.4.1. Scatter plot Diagram

\section{$\underline{\text { Chart } 6}$}

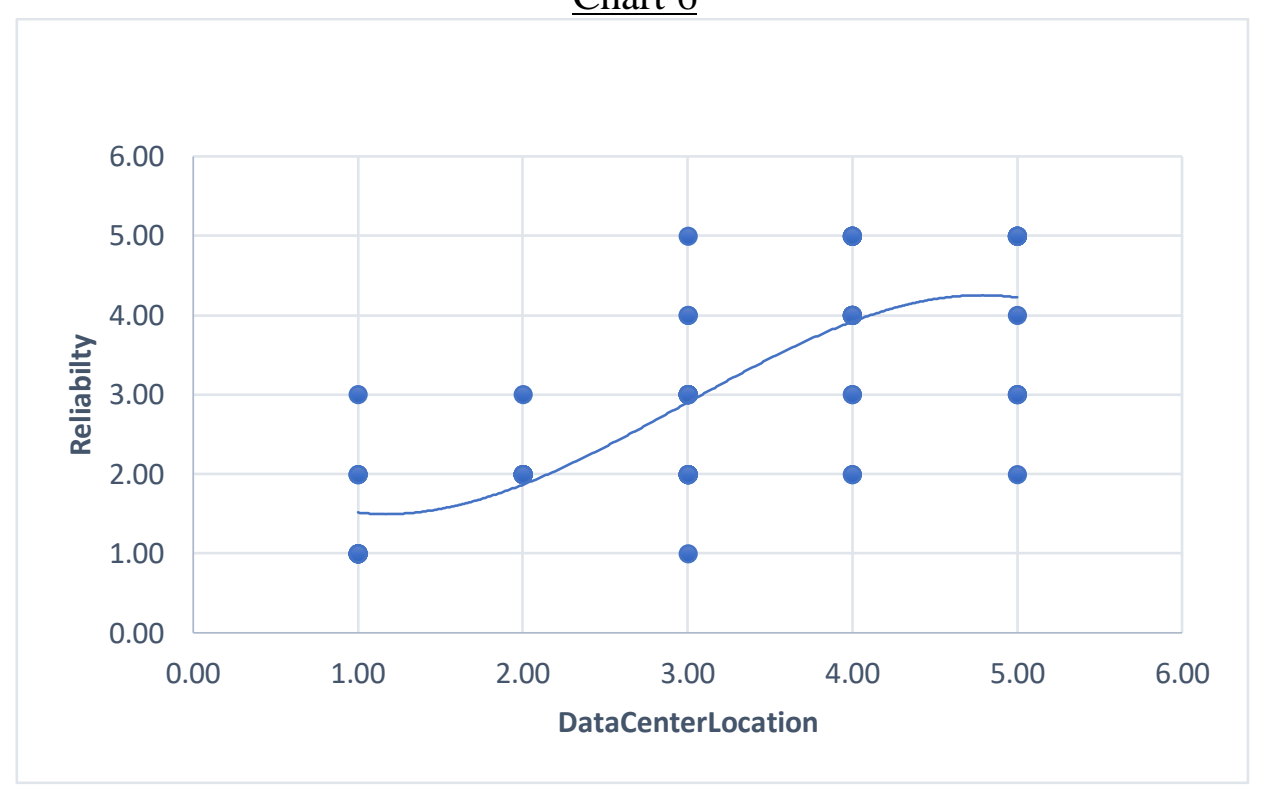

The relationship appears monotonic (assessed via scatterplot). There is a monotonic component to the association, as the value of reliability increases, so does the value of the data center location.

Since both are ranked variable, we can run Spearman's correlation to measure the strength and direction of this monotonic relationship. 


\begin{tabular}{|c|c|c|c|c|c|c|}
\hline \multicolumn{7}{|c|}{ Table16- Case Processing Summary } \\
\hline \multirow{7}{*}{} & \multicolumn{7}{c|}{ Cases } \\
\cline { 2 - 7 } & \multicolumn{2}{|c|}{ Valid } & \multicolumn{2}{c|}{ Missing } & \multicolumn{2}{c|}{ Total } \\
\cline { 2 - 7 } & $\mathrm{N}$ & Percent & $\mathrm{N}$ & Percent & $\mathrm{N}$ & Percent \\
\cline { 2 - 7 } & 76 & $90.5 \%$ & 8 & $9.5 \%$ & 84 & $100.0 \%$ \\
\hline $\begin{array}{c}\text { Reliabilty } * \\
\text { DataCenterLocation }\end{array}$ & & & & & & \\
\hline
\end{tabular}

\begin{tabular}{|c|c|c|c|c|c|c|c|}
\hline \multicolumn{8}{|c|}{ Table 17- Reliabilty * DataCenterLocation Crosstabulation } \\
\hline \multicolumn{8}{|c|}{ Count } \\
\hline & & \multicolumn{5}{|c|}{ DataCenterLocation } & \multirow[b]{2}{*}{ Total } \\
\hline & & 1.00 & 2.00 & 3.00 & 4.00 & 5.00 & \\
\hline \multirow[t]{5}{*}{ Reliabilty } & 1.00 & 7 & 0 & 1 & 0 & 0 & 8 \\
\hline & 2.00 & 3 & 11 & 8 & 2 & 1 & 25 \\
\hline & 3.00 & 1 & 1 & 9 & 2 & 3 & 16 \\
\hline & 4.00 & 0 & 0 & 2 & 9 & 1 & 12 \\
\hline & 5.00 & 0 & 0 & 1 & 7 & 7 & 15 \\
\hline \multicolumn{2}{|c|}{ Total } & 11 & 12 & 21 & 20 & 12 & 76 \\
\hline
\end{tabular}

\begin{tabular}{|c|c|c|c|c|c|}
\hline \multicolumn{7}{|c|}{ Table 18- Symmetric Measures } \\
\hline & Value & $\begin{array}{c}\text { Asymptotic } \\
\text { Standard Error }\end{array}$ & Approximate $\mathrm{T}^{\mathrm{b}}$ & $\begin{array}{c}\text { Approximate } \\
\text { Significance }\end{array}$ \\
\hline Interval by Interval & Pearson's R & .746 & .055 & 9.642 & $.000^{\mathrm{c}}$ \\
\hline Ordinal by Ordinal & Spearman Correlation & .757 & .056 & 9.967 & $.000^{\mathrm{c}}$ \\
\hline \multicolumn{7}{|c|}{ N of Valid Cases } & 76 & & \\
\hline \multicolumn{7}{|c|}{ Based on normal approximation. } \\
\hline
\end{tabular}

Here the significance Value is 0.00 so, we will reject the null hypothesis $\left(\mathrm{H}_{0}\right)$ and accept the alternative hypothesis $\left(\mathrm{H}_{\mathrm{a}}\right)$. So, these two variables have strong association since Spearman Correlation value is 0.757 and in positive direction that means Reliability on Cloud Computing will increase if Data Center Location Reliability will increase.

This proves,

There is significant association between Reliability on Cloud Computing and the Location of Data Center of Cloud Computing for bringing Disruption in IT Service Industry

\subsubsection{Hypothesis 3 Testing}

Null Hypothesis $\left(\mathbf{H}_{\mathbf{0}}\right)$ : There is no significant association between Organization Culture and the Disruptionbrought by Cloud Computing in IT Service Industry

Alternative Hypothesis $\left(\mathbf{H}_{\mathbf{a}}\right)$ : There is significant association between Organization Culture and the Disruptionbrought by Cloud Computing in IT Service Industry 


\subsection{Scatter plot Diagram}

\section{$\underline{\text { Chart } 7}$}

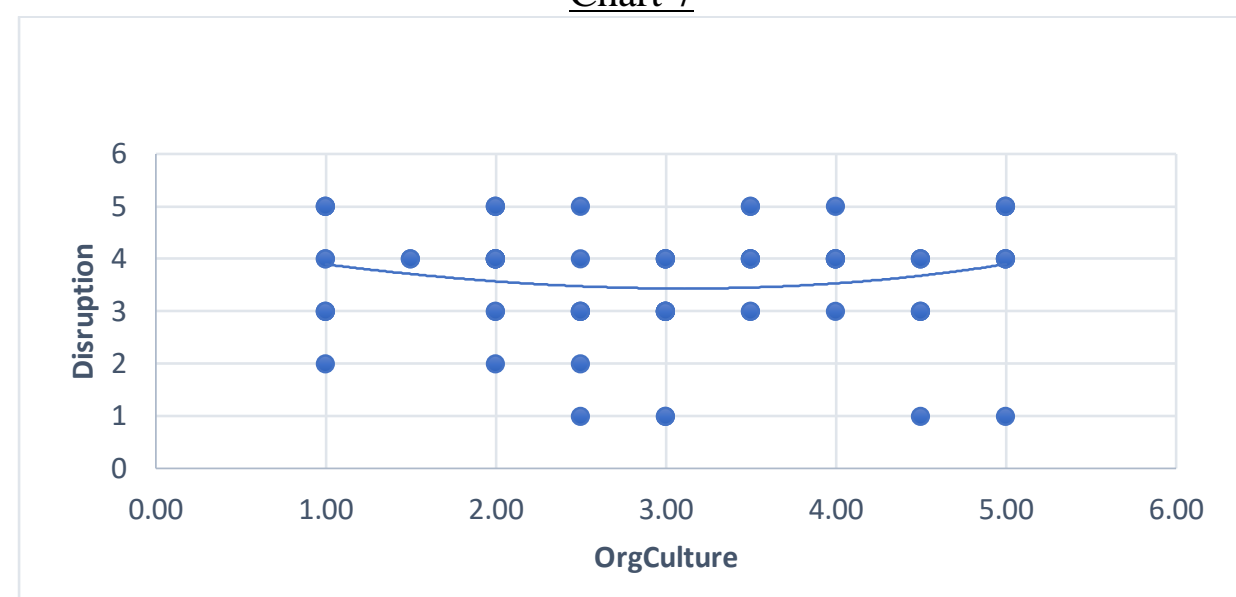

The relationship appears non-monotonic (assessed via scatterplot).there is a non-monotonic component to the association, as the value of disruption in Cloud Computingis not associated with Organisation Culture.

Since both are ranked variable, we can run a Spearman's correlation on a non-monotonic relationship to determine if there is a monotonic component to the association.

\subsection{Spearman Correlation}

\section{Table 19- Case Processing Summary}

\begin{tabular}{|l|l|l|l|l|l|l|}
\hline \multicolumn{2}{|l|}{ Cases } & \multicolumn{4}{l|}{} \\
\cline { 2 - 7 } & Valid & Missing & Total & \\
\cline { 2 - 7 } & $\mathrm{N}$ & Percent & $\mathrm{N}$ & Percent & $\mathrm{N}$ & Percent \\
\hline Disruption * OrgCulture & 76 & $90.5 \%$ & 8 & $9.5 \%$ & 84 & $100.0 \%$ \\
\hline
\end{tabular}

\section{Table 20- Disruption * OrgCulture Crosstabulation}

\section{Count}

\begin{tabular}{|c|c|c|c|c|c|c|c|c|c|c|c|}
\hline & \multicolumn{9}{|c|}{ OrgCulture } & \multirow[b]{2}{*}{ Total } \\
\hline & & 1.00 & 1.50 & 2.00 & 2.50 & 3.00 & 3.50 & 4.00 & 4.50 & 5.00 & \\
\hline \multirow[t]{5}{*}{ Disruption } & 1 & 0 & 0 & 0 & 1 & 2 & 0 & 0 & 1 & 1 & 5 \\
\hline & 2 & 1 & 0 & 1 & 1 & 0 & 0 & 0 & 0 & 0 & 3 \\
\hline & 3 & 3 & 0 & 2 & 4 & 7 & 2 & 1 & 3 & 0 & 22 \\
\hline & 4 & 2 & 2 & 7 & 1 & 5 & 4 & 5 & 3 & 4 & 33 \\
\hline & 5 & 3 & 0 & 3 & 1 & 0 & 2 & 1 & 0 & 3 & 13 \\
\hline Total & & 9 & 2 & 13 & 8 & 14 & 8 & 7 & 7 & 8 & 76 \\
\hline
\end{tabular}

Note:Org Culture is the combined variable calculated by taking average of Management Decision for innovation and Organization politics that the reason it has decimal values in rating. 
ISSN No:-2456-2165

\begin{tabular}{|c|c|c|c|c|c|}
\hline \multicolumn{7}{|c|}{ Table 21- Symmetric Measures } \\
\hline \\
\hline Interval by Interval & Pearson's R & -.002 & $\begin{array}{c}\text { Asymptotic } \\
\text { Standard Error }\end{array}$ & Approximate $\mathrm{T}^{\mathrm{b}}$ & $\begin{array}{c}\text { Approximate } \\
\text { Significance }\end{array}$ \\
\hline Ordinal by Ordinal & Spearman Correlation & .031 & .120 & -.018 & $.986^{\mathrm{c}}$ \\
\hline \multicolumn{7}{|c|}{ N of Valid Cases } & 76 & .266 & $.791^{\mathrm{c}}$ \\
\hline \multicolumn{7}{|c|}{ Based on normal approximation. } \\
\hline
\end{tabular}

Here the significance Value is 0.791 so, we will accept the null hypothesis $\left(\mathrm{H}_{0}\right)$ and reject the alternative hypothesis $\left(\mathrm{H}_{\mathrm{a}}\right)$. So, these two variables have no association since Spearman Correlation value is 0.031 which implies no or very weak association and there is no monotonic component in the relationship.

This proves,

There is no significant association between Organization Culture and the Disruption brought by Cloud Computing in IT Service Industry. 


\section{CHAPTER 4 FINDINGS AND OBSERVATIONS}

1. The population agrees that cloud Computing has brought disruption in IT service Industry

2. Female population agrees more as compared to male population on the statement

3. Population irrespective of the technical knowledge about the Cloud Computing agrees that Cloud Computing has brought Disruption and will continue to bring.

4. Population who has used Cloud both professionally and personally are more positive about Disruption.

5. Security of Cloud Computing is positively affected by the Compliance and Standards.

6. Reliability of Cloud increases with Localization of Data

7. Management willingness to Innovate and organization politics does not effects Disruption of Cloud Computing 


\section{CHAPTER 6 CONCLUSION}

1. The cloud computing ha great impact on IT Service Industry and still evolving and have high potential to explore AI and Automation, Blockchains, Big Data etc.

2. There are concerns and criticism regarding security, availability, confidentiality and integrity of data on cloud, but these can be resolved by best practices and being complied with various standards and policies.

3. The organisations who doubt on capabilities of cloud will lag and they should bug up to adopt the technology in order to survive in the competitive market.

4. The new roles have been introduced in the IT service Industry but still they are not well defined.

Reference Tables

\section{ANNEXURES}

Internal consistency

\begin{tabular}{|c|c|}
\hline Cronbach's alpha & Internal consistency \\
\hline $0.9 \leq \alpha$ & Excellent \\
\hline $0.8 \leq \alpha<0.9$ & Good \\
\hline $0.7 \leq \alpha<0.8$ & Acceptable \\
\hline $0.6 \leq \alpha<0.7$ & Questionable \\
\hline
\end{tabular}

Association between Variables

\begin{tabular}{|c|c|}
\hline $\begin{array}{c}\text { Spearman's correlation } \\
\text { coefficient }\end{array}$ & Degree of Association \\
\hline $.00-.19$ & very weak \\
\hline $.20-.39$ & weak \\
\hline $.40-.59$ & moderate \\
\hline $.60-.79$ & strong \\
\hline $.80-1.0$ & very strong \\
\hline
\end{tabular}




\section{REFERENCES}

[1]. Wiseman, M. (2018). A history of Cloud Computing. [online] Youcloudit.com. Available at: http://www.youcloudit.com/a-history-of-cloud-computing/ [Accessed 29-Jul-2018].

[2]. Computerweekly.com. (2018). Cloud computing: Past, present and future - Ahead in the Clouds. [online] Available at: https://www.computerweekly.com/blog/Ahead-in-the-Clouds/Cloud-computing-Past-present-andfuture [Accessed 29-Jul-2018].

[3]. Uni-trier.de. (2018).

[online] Available

at: $\quad$ https://www.unitrier.de/fileadmin/fb4/prof/VWL/IWB/Vorlesung/neu/DECLARATION_OF_ORIGINALITY_01.pdf [Accessed 29-Jul-2018].

[4]. Startupgrind.com. (2018). What Is Disruption, Really? 8 Examples and What to Learn From Them. [online] Available at: https://www.startupgrind.com/blog/what-is-disruption-really-8-examples-and-what-to-learn-fromthem/ [Accessed 29-Jul-2018].

[5]. "Spearman's Rank-Order Correlation," Spearman's Rank-Order Correlation - A guide to when to use it, what it does and what the assumptions are. [Online]. Available: https://statistics.laerd.com/statistical-guides/spearmansrank-order-correlation-statistical-guide.php. [Accessed: 26-Oct-2018]

[6]. "HOME," IDRE Stats. [Online]. Available: https://stats.idre.ucla.edu/spss/faq/what-does-cronbachs-alphamean/. [Accessed: 26-Oct-2018]

[7]. Q. Hardy, "How Cloud Computing Is Changing Management," Harvard Business Review, 21-Feb-2018. [Online]. Available: https://hbr.org/2018/02/how-cloud-computing-is-changing-management. [Accessed: 29-Jul2018]

[8]. R. Rao, "The cloud impact on outsourcing to India," ZDNet, 14-Jul-2017. [Online]. Available: https://www.zdnet.com/article/the-cloud-impact-on-outsourcing-to-india/. [Accessed: 29-Jul-2018(Gonzalez, 2014)]

[9]. F. E. Online, "What the future holds for India in cloud computing," The Financial Express, 27-Jul-2015. [Online]. Available: https://www.financialexpress.com/industry/technology/what-the-future-holds-for-india-incloud-computing/108207/. [Accessed: 29-Jul-2018]

[10]. National Informatics Centre and Ministry of Electronics and Information Technology, "National Cloud of NIC," National Cloud of NIC. [Online]. Available: https://cloud.gov.in/. [Accessed: 29-Jul-2018]

[11]. Gonzalez, Matthew D. and Smith Jr., Marcus L., "Are Cloud Computing Services Adoption Trends Changing?" Are Cloud Computing Services Adoption Trends Changing? [Online]. Available: http://search.ebscohost.com/login.aspx?direct=true\&db=bth\&AN=102429675\&site=ehost-live. [Accessed: 29Jul-2018]

[12]. Narasimhan, Sridhar, Niculescu, Marius Florin, and Wu, D. J., "TECHNOLOGY SUPPORT AND POSTADOPTION IT SERVICE USE: EVIDENCE FROM THE CLOUD.," Sep-2018. [Online]. Available: http://search.ebscohost.com/login.aspx?direct=true\&db=buh\&AN=131142275\&site=ehost-live. [Accessed: 29Jul-2018]

[13]. Chen, Thomas, Ta-Tao Chuang, and Kazuo Nakatani, "The Perceived Business Benefit of Cloud Computing: An Exploratory Study," $2016 . \quad$ [Online]. Available: http://search.ebscohost.com/login.aspx?direct=true \&db=bth\&AN=122416572\&site=ehost-live. [Accessed: 29Jul-2018]

[14]. Zhou, Bowen; Buyya, Rajkumar, “Augmentation Techniques for Mobile Cloud Computing,” Jan-2018. [Online]. Available: $\quad$ http://search.ebscohost.com/login.aspx?direct=true \&db=bth\&AN=127384034\&site=ehost-live.

[Accessed: 29-Jul-2018]

[15]. Noyes, Katherine., "IBM's Cloud CTO: 'We're in this game to win'," 2016. [Online]. Available: http://search.ebscohost.com/login.aspx?direct=true \&db=bth\&AN=117089641\&site=ehost-live. [Accessed: 29Jul-2018]

[16]. Choudhary, Vidyanand; Vithayathil, Joseph., "The Impact of Cloud Computing: Should the IT Department Be Organized as a Cost Center or a Profit Center?," 2013. [Online]. Available: http://search.ebscohost.com/login.aspx?direct=true \&db=bth\&AN=93255288\&site=ehost-live. [Accessed: 29Jul-2018] 